\title{
Measuring the Intra-individual Variability of the Plasma Proteome in the Chicken Model of Spontaneous Ovarian Adenocarcinoma
}

\author{
Adam M. Hawkridge ${ }^{1,{ }^{*}}$, Rebecca B. Wysocky ${ }^{2}$, James N. Petitte ${ }^{2}$, Kenneth E. Anderson ${ }^{2}$, \\ Paul E. Mozdziak ${ }^{2}$, Oscar J. Fletcher ${ }^{3}$, Jonathan M. Horowitz ${ }^{4}$, and David C. Muddiman ${ }^{1}$ \\ ${ }^{1}$ W. M. Keck FT-ICR Mass Spectrometry Laboratory and Department of Chemistry, North \\ Carolina State University, Raleigh, NC 27695 \\ 2Department of Poultry Science, North Carolina State University, Raleigh, NC 27695 \\ ${ }^{3}$ Department of Population Health and Pathobiology, North Carolina State University, Raleigh, NC \\ 27695 \\ ${ }^{4}$ Department of Molecular Biomedical Sciences, North Carolina State University, Raleigh, NC \\ 27695
}

\begin{abstract}
The domestic chicken (Gallus domesticus) has emerged as a powerful experimental model for studying the onset and progression of spontaneous epithelial ovarian cancer (EOC) with a disease prevalence that can exceed 35\% between 2-7 years of age. A novel experimental strategy for biomarker discovery is reported herein that combines the chicken model of EOC, longitudinal plasma sample collection with matched tissues, advanced mass spectrometry-based proteomics, and concepts derived from the index of individuality. Blood was drawn from 148 age-matched chickens starting at 2.5 years of age every three months for one-year. At the conclusion of the oneyear sample collection period, the 73 birds that remained alive were euthanized, necropsied, and tissues were collected. Pathological assessment of resected tissues from these 73 birds confirmed that 5 birds $(6.8 \%)$ developed EOC. A proteomics workflow including in-gel digestion, nanoLC coupled to high performance mass spectrometry, and label-free (spectral counting) was used to measure the biological intra-individual variability $\left(\mathrm{CV}_{\mathrm{W}}\right)$ of the chicken plasma proteome. Longitudinal plasma sample sets from two birds within the 73-bird biorepository were selected for this study; one bird was considered "healthy" and the second bird developed late-stage EOC. A total of 116 proteins from un-depleted plasma were identified with 80 proteins shared among all sample sets. Within- and between-run analytical variability $\left(\mathrm{CV}_{\mathrm{A}}\right)$ of the label-free proteomics workflow was measured using a single plasma sample analyzed multiple times. Ovomacroglobulin (ovostatin) was found to increase over a 6 month period in the late-stage EOC bird providing an initial candidate protein for further investigation.
\end{abstract}

\footnotetext{
*Corresponding Author: Adam M. Hawkridge, Ph.D., W. M. Keck FT-ICR Mass Spectrometry Laboratory, Department of Chemistry, North Carolina State University, Box 8204, Raleigh, NC 27695, Phone: 919-513-7947, Fax: 919-513-7993,

adam_hawkridge@ncsu.edu.

SUPPLEMENTARY INFORMATION

A detailed description of the biorepository sample collection protocol (Figure S1), pathology (Table S1), ingel digestion protocol (Figure S2), apomyoglobin standard preparation (Figure S3), bird mortality rate (Figure S4), retention time reproducibility (Figure S5), and a full list of proteins with corresponding SpC data (Table S2, Excel Spreadsheet) are provided. The data, databases (target and decoy), and pertinent experimental information associated with this manuscript may be downloaded from the ProteomeCommons.org Tranche network using the following hash: uugfN1BF6UPG13TCbP3DtHNjyBO70RLhVrBxakHjFJ +rPu6pzhdr7ZbOGlMmvRohwvg7D6pMOfkF0xtmjkOYvIX8e7MAAAAAAADrgQ==
} 


\section{INTRODUCTION}

Epithelial ovarian cancer (EOC) remains the most lethal gynecological cancer in the Western world due to a combined lack of effective therapeutic and diagnostic screening strategies. The 5-year survival rates for EOC patients diagnosed during the early stage (Stage I) of the disease approach $90 \%$ compared with $30 \%$ for Stage III and IV EOC. However, due to the nonspecific symptoms associated with EOC and the absence of earlystage screening strategies, only $20 \%$ of women are diagnosed at Stage I when surgical and therapeutic strategies are most effective. ${ }^{1}$ The predictive value of several candidate early stage EOC biomarkers have been explored including physical symptoms, genes, proteins, metabolites, and in vivo tumor imaging in an effort to improve mortality. ${ }^{2}$ The most promising EOC biomarkers identified to date include cancer antigen 125 (CA-125) ${ }^{3,4}$ and trans-vaginal ultrasound ${ }^{5}$. Despite the promising diagnostic potential of these biomarkers, their specificity is insufficient either individually or in conjunction with each other ${ }^{6}$ for use as a population-wide screening module for detection of early-stage EOC. Continued efforts have focused on identifying more predictive EOC biomarkers but have been slowed by a confluence of factors including the pathogenic heterogeneity of the disease, short supply of early stage clinical specimens, and inadequate in vitro and in vivo experimental models. ${ }^{7-13}$

Experimental models of human cancers are important for studying cellular neoplastic transformation, establishing therapeutic efficacy, and identifying candidate biomarkers. However, EOC has proven to be very difficult to model relative to other cancers for a number of reasons. EOC originates in the ovarian surface epithelium (OSE) which is a distinct monolayer of flat-to-cuboidal cells that line the human ovary. ${ }^{7-13}$ Relatively little is known about the normal OSE because it is difficult to obtain large quantities of cells with high purity and they are extremely sensitive to culture conditions. ${ }^{7}$ In cases where human EOC tumor tissues have been collected, isolated tumorigenic cells from these clinical specimens have been used to generate immortalized cell lines or have been injected into immunodeficient mice to study metastasis and treatment efficacy. ${ }^{14}$ However, these methodologies undoubtedly affect cell physiology and malignancy limiting the relevance of the study. Another experimental approach to modeling EOC involves the development of transgenic mice carrying genes known to be involved in ovarian tumorigenesis. ${ }^{15-19}$ However, transgenic mice that faithfully mimic the onset of EOC have yet to be developed. ${ }^{20}$ Such a model would be important for functional studies and for identifying EOC biomarkers. In an effort to overcome the limitations of existing experimental approaches in EOC research and identify effective biomarkers for early-stage screening, we developed a large-scale biospecimen repository for the chicken model of spontaneous EOC and present initial proteomic results.

The domestic chicken (Gallus domesticus) is an outstanding animal model for EOC due in large part to the high prevalence of spontaneous ovarian adenocarcinomas over a relatively narrow window of time. Reports of EOC in chickens dates back to a brief study by $\mathrm{J}$. E. Wilson who showed in 1958 that 16 out of 19 chickens developed ovarian adenocarcinomas after 500 days post-hatch. ${ }^{21}$ Some years later T. N. Fredrickson monitored the status of 466 chickens over a 2-7 year period and observed that between 5-35\% of the birds developed EOC depending on the genetic strain. ${ }^{22}$ Since these initial studies, research has focused on characterizing the tumor tissues at the molecular level using immunohistochemistry, RTPCR, and Western blotting in comparison to humans. ${ }^{23-29}$ Important commonalities include the differential expression of CA- $125^{26}$, similar mutational frequencies of $\mathrm{p} 53^{28}$ relative to humans, and over-expression of Her-2/neu in EOC tumors. ${ }^{28}$ Furthermore, reduced egg production in chickens correlates with fewer cases of $\mathrm{EOC}^{28}$ agreeing with the incessant ovulation hypothesis proposed by Fathalla et al. ${ }^{30}$ The combination of high EOC prevalence over a predictable window of time (2-4 years of age), the short onset time relative to 
humans, molecular-level similarities to human EOC, and the ability to draw several milliliters of blood without sacrificing the animal provide a unique experimental model for early-stage EOC biomarker discovery.

Mass spectrometry (MS) is a central technology platform for many protein biomarker discovery efforts including EOC. ${ }^{31}$ MS-based methods have been used to identify candidate protein EOC biomarkers in a variety of studies involving ovarian cell lines ${ }^{32-37}$, pre- and neoplastic tissues ${ }^{38-41}$, ascites fluid ${ }^{42,43}$, plasma $^{36}$, and serum ${ }^{44-50}$. However, most MSbased biomarker discovery workflows involving samples such as plasma, serum, ascites, and tumor tissues involve a "single individual-single sample" approach for establishing the "healthy" and "disease" biospecimens. ${ }^{31}$ In other words, a single sample is collected from each patient in the study, all of whom have been classified as either "healthy" or "diseased" and these samples are assumed to be representative of the two populations. The subsequent MS-based proteomic datasets derived from these two groups are mined for statistically significant up- or down-regulated proteins that could be used as potential biomarkers. A shortcoming of this approach is that there is substantial evidence showing that the concentrations of some biochemical constituents, including proteins, fluctuate significantly within healthy individuals making it difficult, if not impossible, to define true populationbased "healthy" or "disease" ranges for some biomolecular species, potentially including novel early-stage EOC biomarkers.

A landmark series of papers appearing more than 40 years ago reported the concentrations of 15 biochemical constituents in blood from 68 "healthy" individuals as a function of time. ${ }^{51-55}$ The researchers went to great effort to understand and quantify the analytical, intra-individual biological, and inter-individual biological components of variability for each of the 15 analytes. Importantly, the research showed that analytical variability was analyte and day-of-analysis dependent, for some analytes the analytical variability was greater than the biological variability, and that for some analytes intra-individual biological variability was greater than inter-individual variability. These systematic observations led to the formulation the index of individuality (Equation 1)

$$
\text { Index of Individuality }=\frac{\sqrt{C V_{A}^{2}+C V_{W}^{2}}}{C V_{B}}
$$

which is "a numerical index for combining intra- $\left[\mathrm{CV}_{\mathrm{W}}\right]$ and inter-individual $\left[\mathrm{CV}_{\mathrm{B}}\right]$ variation for use in judging the appropriateness of applying a conventional normal range to an individual measurement of some biochemical constituent" $\left(\mathrm{CV}_{\mathrm{A}}=\right.$ analytical $) .{ }^{56} \mathrm{Using}$ this metric, it has been shown that the concentrations of many clinical analytes in blood are specific to individuals including vitamins (A, B-12, and E), cholesterol, alkaline phosphatase, serum albumin, apolipoproteins $\mathrm{A}$ and $\mathrm{B}$, and total protein. ${ }^{57}$ With respect to EOC and breast cancer, serial quantitative ELISA measurements of tumor markers such as CA 15.3 and CA-125 $5^{58-61}$ showed that these biomarker concentrations were specific to individuals (low index of individuality < 0.6 ) and that individual-specific cut-off values improved the positive predictive values of the tests. The significance of these data has clear implications for biomarker discovery experimental designs that utilize clinical specimens. If the concentration and variability of certain proteins are specific to a healthy individual ${ }^{62-64}$, one can expect that the concentration changes for many of these proteins at the onset of disease may also be specific to the individual, even if the proteins do not originate from the tumor tissue. ${ }^{49,}, 65$

This study represents our initial attempts to incorporate concepts rooted in the index of individuality ${ }^{56}$ with advanced MS-based global proteomics technology and label-free 
quantification to identify early-stage EOC biomarkers. The underlying hypothesis is that personalized reference ranges established using quantitative MS-based proteomics will serve as a new approach to identifying candidate biomarkers in EOC. Towards this end, we describe the establishment of a large biospecimen repository of longitudinal plasma samples collected from 148 age-matched 2.5 year-of-age B-strain birds every 3 months for one year. The 73 birds that remained alive at the conclusion of the one-year period were euthanized and tissue samples were collected for pathology and proteomic analysis. Pathological assessment of these tissue specimens confirmed that 5 birds (6.8\%) had spontaneously developed EOC. Using a small subset of samples from this biorepository, we estimated the within and between-run analytical variability of the workflow used in this study and measured the plasma proteome intra-individual variability for two birds, one that was considered healthy and a second that developed late-stage EOC with extensive metastasis.

\section{EXPERIMENTAL}

\section{Reagents}

Coomassie Plus ${ }^{\mathrm{TM}}$ assay reagents including the bovine serum albumin standard for total protein concentration were purchased from PIERCE (Rockford, IL). Dithiothreitol (DTT), Laemmli buffer, 1M Tris/Glycine/SDS running buffer, and Coomassie G-250 were obtained from Bio-Rad (Hercules, CA). Iodoacetamide, Tris-HCl, ammonium bicarbonate, LC-MS grade formic and acetic acid, and sequencing grade apomyoglobin were purchased from SIGMA-Aldrich (St. Louis, MO). HPLC-grade $\mathrm{H}_{2} \mathrm{O}$ and ACN were purchased from Burdick \& Jackson (Honeywell, Morristown, NJ) and used as received. ACS reagent grade glacial acetic acid and phosphoric acid were purchased from Fisher Scientific (Pittsburgh, PA). Trypsin (Trypsin Gold, Mass Spectrometry Grade) was purchased from Promega (Madison, WI).

\section{Animal Care, Biospecimen Collection, and Pathology}

150 age-matched B-strain hens were obtained at 2 years of age from the North Carolina Department of Agriculture and Consumer Services, Piedmont Research Facility in Salisbury, NC in May 2007 and transported to the North Carolina State University Lake Wheeler Poultry Science Facility in Raleigh, NC. The flock of 150 birds was managed in accordance with the Institute for Laboratory Animal Research Guide with all of the husbandry practices being approved by and under the oversight of North Carolina State University Institutional Animal Care and Use Committee (IACUC). Birds were tagged and paired in $2^{\prime} \times 2^{\prime} \times 2^{\prime}$ cages that were housed within a single sheltered building. The health and egg-laying status of the flock was monitored daily and the diet for all birds was provided $a d$ libitum.

A detailed description of the sample collection, sample storage, and bird mortality is provided in Supplementary Information (Figure S1). Briefly, approximately $2 \mathrm{ml}$ of blood was drawn from the birds every three months for one-year starting at 2.5 years of age ( 5 time points total). Due to natural mortality, 73 birds remained at the conclusion of the oneyear study. Blood collection started at the same time for each of the 5 time points to minimize daily variability in blood composition (e.g., circadian rhythms). The collected blood samples were centrifuged at $3000 \times \mathrm{g}$ for 3 minutes at $10^{\circ} \mathrm{C}$, the resulting plasma transferred to cryogenic tubes, and immediately placed on dry ice.

Tissues were collected from birds that presented neoplastic lesions on the ovaries and from selected birds that showed no presence of neoplastic lesions or other signs of distress (i.e., "healthy"). Tissues were preserved for both pathological (formalin fixation) and proteomic $\left(\mathrm{LN}_{2}\right.$ snap frozen) characterization. Fixed tissues were imbedded in paraffin wax, 
microtomed into $10 \mu \mathrm{m}$-thick sections and adhered to slides, and then stained with hematoxylin and eosin (H\&E). H\&E stained slides were assessed by a board-certified veterinary pathologist.

\section{Longitudinal Plasma Samples}

Three sets of plasma samples were analyzed in this study to estimate within- and betweenrun analytical variability and biological variability. A single plasma sample from a bird (herein described as "Analytical") with no visible signs of distress was used to measure the analytical variability of the proteomics workflow in this study. The plasma proteome intraindividual variabilities of 2 birds from the biospecimen repository were measured as a function of health status. One bird (i.d. \# 602B Supplementary Information: Table S1), hereafter described as "Healthy", was found to have a cystic right oviduct, fatty liver, and normal functioning ovary with no visible signs of distress prior to euthanization and no signs of neoplastic lesions at the time of necropsy. The second bird (i.d. \# 650B Supplementary Table S1), hereafter described as "EOC", was found to have advanced ovarian adenocarcinoma and neoplastic lesions on adjacent organs including the oviduct, intestines, pancreas, and liver at the time of necropsy. Pathological characterization of the neoplastic lesions resected from the EOC bird established that the ovarian tumor was epithelial and that the oviductal tumor was benign.

\section{In-gel Digestion}

Total protein concentrations for the Healthy, EOC, and Analytical plasma samples were determined using a Bradford assay (Coomassie Plus ${ }^{\mathrm{TM}}$ ). The standard curve was generated using serial dilutions of bovine serum albumin per the manufacturer's instructions. Absorbance values for each sample were measured in triplicate at $595 \mathrm{~nm}$ using a Shimadzu UV-1800 Spectrophotometer (Columbia, MD). The plasma samples were diluted to 1-2 $\mu \mathrm{g} /$ $\mu \mathrm{l}$ with $62.5 \mathrm{mM}$ Tris- $\mathrm{HCl}(\mathrm{pH} 6.8)$ and combined with freshly prepared DTT/Laemmli loading buffer $(54 \mathrm{mg} / \mathrm{ml})$ in a 1:2 (v:v) ratio. The resulting solutions were briefly vortexed and then heated at $95^{\circ} \mathrm{C}$ for 5 minutes. $28 \mu \mathrm{l}(\sim 35-50 \mu \mathrm{g}$ total protein) aliquots of each reduced sample were loaded onto a Bio-Rad Criterion Tris-HCl precast 1D gel (12.5\% Tris$\mathrm{HCl}, 12$-well) and were run at a constant $200 \mathrm{~V}$ for approximately 45-60 minutes until the leading edge of the loading buffer reached a distance of 1" from the table. The gels were stained using a colloidal Coomassie method developed by Candiano et al. ${ }^{66}$ After destaining the gels, they were rinsed with DI $\mathrm{H}_{2} \mathrm{O}$ and then transferred to a Laminar flow hood for ingel digestion.

The details of the in-gel digestion protocol are shown in Supporting Information (Figure S2). Briefly, a total of 36 gel bands per lane were prepared using $2 \mathrm{~mm} \times 7 \mathrm{~mm}$ grid cutters (The Gel Company, San Francisco, CA) and transferred to 8 vials. The in-gel digestion protocol was adapted from Shevchenko et al. ${ }^{67}$ Trypsin digested samples were combined into 4 fractions per gel lane, dried in a speedvac, reconstituted in $200 \mu 1$ of mobile phase A, transferred to 96 -well plates, and then stored at $-80^{\circ} \mathrm{C}$.

\section{nanoLC-MS/MS}

Samples were analyzed using a splitless 2D nanoLC system (Eksigent, Dublin, CA) coupled to a LTQ-Orbitrap mass spectrometer (Thermo Fisher, San Jose, CA) via a vented column assembly detailed in Supplementary Figure S2 ${ }^{68}$ The vented column consisted of a $75 \mu \mathrm{m} \times$ $5 \mathrm{~cm}$ trap (IntegraFrit: New Objective, Woburn, MA) coupled to a $75 \mu \mathrm{m} \times 10 \mathrm{~cm}$ analytical column with a $15 \mu \mathrm{m}$ emitter tip (PicoFrit: New Objective, Woburn, MA). Both the trap and column were self-packed with MAGIC C18AQ, $5 \mu \mathrm{m}, 200 \AA$ A stationary phase (Michrom Bioresources, Auburn, CA). Mobile phases A and B consisted of $\mathrm{H}_{2} \mathrm{O}: \mathrm{ACN}(98: 2$, v/v) w/ $0.2 \%$ formic acid and $\mathrm{H}_{2} \mathrm{O}: \mathrm{ACN}(10: 90$, v/v) w/0.2\% formic acid respectively. Samples 
from each 96-well plate were run randomly in triplicate with an apomyoglobin digest standard run at the beginning and after every $5^{\text {th }}$ sample injection (see Supplementary Figure $\mathrm{S} 3$ for details). $2 \mu \mathrm{l}$ of sample was loaded onto the vented column trap at $2 \mu \mathrm{l} / \mathrm{min}$ ( $2 \% \mathrm{~B}$ ) followed by the equivalent of 10 trap washes. After washing the sample, the valve was diverted and the following gradient was applied @ $350 \mathrm{~nL} / \mathrm{min}: 0-5 \mathrm{~min}(2 \% \mathrm{~B}), 5-63 \mathrm{~min}$ (2-45\% B), 63-70 $\min (45-90 \%$ B), 70-73 $\min (90 \%$ B), 73-75 $\min (90-2 \%$ B), and 75-82 $\min (2 \% \mathrm{~B})$. Mass spectral data acquisition was initiated 5 minutes after the start of the nLC gradient.

The LTQ-Orbitrap was mass-calibrated before each longitudinal sample set was analyzed using the calibration procedure and mixture recommended by the manufacturer (ThermoFisher, San Jose, CA). The instrument was used in lock-mass mode with AGC limits of $\mathrm{LTQ}_{\mathrm{AGC}}=5 \times 10^{4}$ and Orbitrap $\mathrm{AGC}=1 \times 10^{6}$. The full survey scans were collected at $400-1600 \mathrm{~m} / \mathrm{z}$ with a resolving power of $60,000_{\mathrm{FWHM}}$ at $\mathrm{m} / \mathrm{z}=400$ followed by $6 \mathrm{MS} / \mathrm{MS}$ scans. The dynamic exclusion time was set to 3 minutes.

\section{Data Analysis}

LC-MS/MS data was searched against separate target (IPI Chicken v 3.49) and decoy (random IPI Chicken v $3.49 \rightarrow$ Mascot Perl script: "decoy.pl.gz") protein databases using Mascot Daemon (ver. 2.2.2, Matrix Science) to batch process files, Mascot Distiller (ver. 2.2.1.0, Matrix Science) to generate peak lists, and then Mascot (Matrix Science, Boston, MA) to perform the searches. Carbamidomethyl (C) was set as a fixed modification and deamidation (NQ) and oxidation (M) were set as variable modifications. Additional search settings included maximum missed cleavage $=1$, peptide tolerance $= \pm 3 \mathrm{ppm}$, and MS/MS tolerance $= \pm 0.6 \mathrm{Da}$. Protein grouping, statistical filtering, and quantification (spectral counts) of the Mascot DAT files were accomplished using ProteoIQ (Bioinquire, Athens, GA) that utilizes a combination of Peptide/Protein Prophet ${ }^{69,70}$ and PROVALT ${ }^{71}$. Identified proteins (protein groups) were considered valid with a minimum of 2 peptides, a protein false discovery rate (PRO-FDR) of $1 \%$, and a protein group probability of $\geq 0.9$. All quantitative data reported are in non-normalized spectral counts (i.e., 1 peptide $=1$ spectral count). JMP 8 (SAS, Cary, NC) was used for all statistical analyses.

\section{RESULTS AND DISCUSSION}

\section{Bird Mortality and Pathology}

A total of 150, two year-of-age B-strain hens were selected in May, 2007 for this study based on previously documented high EOC prevalence rates. At the time of the initial blood draw (10/23/2007), 148 birds remained alive. The number of birds alive plotted as a function of time is shown in Supplementary Information (Figure S4). The top axis shows the blood draw dates and the bottom axis shows the study duration in days where day " 0 " is the first blood draw date. Birds were inspected daily to assess health status and identify signs of distress. Linear regression analysis of the data in Figure S4 produced a slope of the line of $-0.22\left(\mathrm{R}^{2}=0.975\right)$ corresponding to a mortality rate of $\sim 3$ bird deaths $/ 2$ weeks. At the conclusion of the study on 10/9/2008, the 73 remaining birds (Figure S4) were bled, euthanized, and necropsied followed by tissue collection and preservation. Out of the original 148 birds in this study, a total of 68 (46\%) were found to have neoplastic lesions on at least one organ. 20 birds from the final 73 were found to have neoplastic lesions on at least one organ which are listed in Supplementary Information (Table S1).

Formalin fixed tissues from the 20 birds (Table S1) were evaluated by a board certified pathologist and 5 out of the final 73 birds $(6.8 \%)$ were confirmed to have EOC. "Early Stage EOC" is defined as an adenocarcinoma confined to the ovary. "Late Stage EOC" is defined 
as the presence of adenocarcinomas on the ovary and neighboring tissues excluding the oviduct. It is very difficult to determine the origin of the primary tumor in cases where adenocarcinomas are present on both the ovary and oviduct. ${ }^{22}$ Thus in this study, birds with tumors on both the ovary and oviduct are defined as "Late Stage EOC/OVD". The exception to this is when one of the tumors is benign such as with the oviductal tumor found in Bird \#650B. "Healthy" birds are defined as having no visible neoplastic lesions inside the body cavity. This does not take into account other deficiencies that might alter the true health status of the bird such as organ dysfunction or nutritional deficiencies. Two birds from the 73 necropsied birds were chosen for this study to measure the intra-individual variability of their respective plasma proteomes. One bird (\#602B) was "Healthy" with no visible signs of distress and the second bird (\#650B) was found to have "Late Stage EOC" with tumors present on the ovary, oviduct (benign), intestines/pancrease, and liver (Table S1). A single plasma sample from a third bird was used to estimate analytical variability. These three sample sets are herein labeled as "Healthy", "EOC", and "Analytical".

Cross-sectional microscopic images of formalin-fixed ovary tissues from the Healthy and EOC birds are shown in Figure 1A-B and 1C-D, respectively. Figure 1A is a 4x image showing the outer surface of a fully functional chicken ovary with the black arrows indicating immature follicles. A higher magnification (20x) of Figure $1 \mathrm{~A}$ in the region defined by the inset box (dashed lines) is shown in Figure 1B. The 20x image (Figure 1B) shows an oocyte within an immature follicle (black arrow) and the ovarian surface epithelium (blue arrow). Figure $1 \mathrm{C}$ is a $4 \mathrm{x}$ image of tumor tissue from the EOC bird showing sheets of neoplastic cells forming cystic glands and nodules (dashed box) invading the ovarian stroma. A higher magnification of Figure $1 \mathrm{C}$ in the dashed box region shows dilated, variable-size glandular structures (yellow arrows) and neoplastic cell nodules (Figure 1D).

\section{Proteome Coverage and Quantification}

The in-gel digested samples for each 1D-gel lane (plasma sample/time point) were combined into 4 fractions and analyzed by LC-MS/MS in triplicate (Supplementary Information Figure S2). In an effort to minimize cross-contamination of samples, each plasma set (i.e., Healthy, EOC, and Analytical) was analyzed on a separate nLC assembly with a new trap and analytical column. An apomyoglobin digest standard was used throughout the analyses as a means to monitor the chromatographic performance within each of the three nLC column assemblies. A total of 16 apomyoglobin digest standard injections were made throughout the analysis of all 4 fractions for each longitudinal plasma set. The retention times of 5 apomyoglobin tryptic peptides were monitored for all three columns and are shown in Supplementary Information Figure S5. Within-column retention time reproducibility for all 5 peaks was $< \pm 20 \mathrm{sec}\left(\mathrm{CIM}_{95 \%}\right)$ for the Healthy bird and $< \pm 10 \mathrm{sec}\left(\mathrm{CIM}_{95 \%}\right)$ for both the EOC and Analytical birds. The between column variability for each peak was $< \pm 1$ minute.

Several experimental methodologies have been developed in recent years to facilitate quantitative MS-based proteomics measurements. ${ }^{72}$ Label-free proteomics encompasses a suite of quantitative strategies including chromatographic peak intensity/area ${ }^{73-77}$ spectral counting $^{78-86}$, or both ${ }^{87,88}$ to measure differentially expressed proteins. Non-normalized spectral counting $(\mathrm{SpC})$ was used in this study to quantitatively measure the plasma proteomes of a Healthy and a late stage EOC (EOC) chicken as a function of time. Figure 2A shows representative 1D gels for the Healthy and EOC birds as well as a single plasma sample (Analytical) loaded onto 5 gel lanes. The time points at the top of the gels represent the blood draw dates where " 1 " = October '07, "2" = January '08, "3" = April "08, "4" = July '08, and " 5 " = October '08. The " $1-5$ " labels above the Analytical gel represent replicates. The total protein loaded onto each lane of the gel is given below each time/ 
replicate point. These quantities are proportional to the original protein concentrations (mg/ $\mathrm{ml}$ ) from the raw plasma samples which were as follows: 1 . Healthy time points $1=35.9 \pm$ $0.2,2=37.2 \pm 0.7,3=33.8 \pm 0.6,4=39.3 \pm 0.0$, and $5=36.6 \pm 1.2 \mathrm{mg} / \mathrm{ml}, 2$. EOC time points $1=34.5 \pm 0.8,2=34.6 \pm 0.6,3=30.1 \pm 0.8,4=33.6 \pm 1.9$, and $5=33.3 \pm 0.6$, and 3. Analytical replicates $1-5=44.4 \pm 1.0$.

Gel bands were cut and digested according to the protocol described in Supplementary Information Figure S2. The number of unique proteins identified by nLC-MS/MS across all 15 lanes, birds (i.e., longitudinal plasma sample sets), and individual gel lanes are shown below the 1D gels in Figure 2A. For example in the Healthy bird; a total of 99, 105, 106, 101, and 103 proteins were identified from the plasma samples at time points 1-5, respectively. There were a total of 112 proteins identified in the Health bird sample set, 92 of which were found in all 5 lanes. A total of 116 unique proteins were identified in this study, of which 80 were found in all 15 plasma samples. The protein set overlap for the Healthy (red), EOC (green), and Analytical (blue) samples are shown in a Venn diagram in Figure 2B. The number of proteins identified as a function of gel lane fraction for the Healthy (red), EOC (green), and Analytical (blue) sample sets are plotted in Figure 2C. Finally, the number of proteins for all 3 sample sets as a function of gel lane fraction is plotted in Figure 2D. The superscripts "a" for \# Proteins Total, "b" for \# Proteins in All 5 Lanes, and "c" for \# Proteins in All 15 Lanes in Figure 2A are provided to directly connect the origin of the data plotted in Figures 2B, 2C, and 2D.

A total of 116 proteins were identified in this study but only 80 were present in all 15 plasma samples enabling intra-individual and inter-individual quantitative comparisons. To be considered "present" in a sample, one peptide (i.e., one spectral count) had to be measured in at least one of the three replicates. Thus, the lowest average spectral count $(\mathrm{SpC})$ for a protein at a given time point is 0.33 with a coefficient of variation $(\mathrm{CV}$ in \%) of 173.2. The individual CV's (i.e., the CV's at each time point, $n=3$ ) for the 80 proteins found in all 15 Healthy, EOC, and Analytical sample sets are plotted as a function of SpC's in Figures 3A, 3B, and 3C, respectively. As expected, the CV's for the average SpC's is inversely proportional to the average $\mathrm{SpC}$. A total of 400 data points comprise each plot in Figures 3A, 3B, and 3C. Histograms plotting the frequency of proteins as a function of individual time point/replicate CV's in $10 \% \mathrm{RSD}(\mathrm{CV})$ bin widths are shown on the right of Figures 3A-3C. More than $50 \%$ of the proteins at individual time points/replicates have CV's less than $20 \%$, and approximately $75 \%$ of the proteins have CV's less than $30 \%$. The significance of these data to a first approximation is that the workflow provided a high degree of precision within samples for these 80 proteins, even for many proteins that have low SpC's $(<10)$.

\section{Intra-individual Variability}

The SpC's for all 116 proteins for each time point and replicate are provided in Supplementary Information (Table S2). Representative longitudinal SpC data from the Healthy (red) and EOC (green) birds are shown in Figure 4 for three plasma proteins including Serum Albumin (Figure 4A), Vitellogenin-1 (Figure 4B), and Transthyretin (Figure 4C). The average $\mathrm{SpC}(\mathrm{Avg} \mathrm{SpC})$ for all 15 data points and intra-individual variability $\left(\mathrm{CV}_{\mathrm{W}}\right)$ of several common proteins including those plotted in Figure 4 are provided in Table 1. Metrics for estimating the analytical variability for these proteins are also shown in Table 1 including the Avg $\mathrm{SpC}$, average CV (Avg CV), analytical variability $\left(\mathrm{CV}_{\mathrm{A}}\right)$, and one-way ANOVA statistics (Prob>F-ratio). The $\mathrm{CV}_{\mathrm{A}}$ is a measure of between gel-lane reproducibility. The Avg CV in Table 1 is a measure of within gel lane precision and should in principle be lower than $\mathrm{CV}_{\mathrm{A}}$. The Prob>F-ratio is the probability of obtaining by chance an F-ratio higher than that calculated from the $\mathrm{SpC}$ data. In other words, the probability the data are wrong and the means for all 5 time points are statistically the same. 
For example, the probability that Prob>F-ratio for serum albumin in the Analytical sample set is $<0.001$ (Table 1) which means that there is very little chance the individual means determined from the $\mathrm{SpC}$ data are in reality the same. Conversely, the alpha-1-antitrypsin "Analytical" $\mathrm{SpC}$ data resulted in a Prob>F-ratio of 0.881 (Table 1) meaning there is a high probability the means for all replicate 5 samples are the same.

Serum albumin, like in humans and other mammals, is the most abundant protein in chicken plasma. In humans, serum albumin has a very low index-of-individuality ${ }^{57}(0.31)$ meaning it's circulating levels are highly specific to the individual. Intra-individual variabilities $\left(\mathrm{CV}_{\mathrm{W}}\right)$ for serum albumin in the Healthy and EOC birds were found to be $9 \%$ and $14 \%$, respectively in close agreement with the $\mathrm{CV}_{\mathrm{A}}$ of $8 \%$ (Table 1). If the index-of-individuality for chickens is comparable to humans (i.e., index-of-individuality $=0.31$ ), the interindividual variability $\left(\mathrm{CV}_{\mathrm{B}}\right)$ would be $\sim 35 \%$. The serum albumin $\mathrm{SpC}$ data in Figure $4 \mathrm{~A}$ for the Healthy bird is $\sim 25 \%$ higher compared with the EOC bird suggesting the $\mathrm{CV}_{\mathrm{B}}$ may exceed the $C V_{W}$. However, additional studies are needed to measure $C_{B}$ including measuring the intra-individual proteomes of a statistically significant number of healthy and EOC birds along with measuring the between-gel analytical variability.

Vitellogenin-1 is used as a biological marker for this study as it shows pronounced changes related to egg production. Vitellogenin-1 is a $200 \mathrm{kDa}$ lipoprotein involved with the collection, transport, and delivery of phosphoglyco-lipids to the growing follicle during egg development. ${ }^{89}$ Vitellogenin-1 concentrations are high in fully functional birds producing eggs and low during molting and reduced egg production (regressed). This can be qualitatively observed in the EOC 1D-gel (Figure 2A) where the staining intensity for time points 3 and 5 at $\sim 200 \mathrm{kDa}$ are diminished. Importantly, baseline levels for both Vitellogenin- 1 are similar for the Healthy and EOC bird except during time points 3 and 5 when egg production in the EOC bird ceased. Transthyretin does not show any appreciable change over time for either bird and both baseline levels (Avg SpC) are identical.

The quantitative data presented up to this point has focused exclusively on 80 proteins, all of which were detected in all 15 samples analyzed in this study. The remaining 36 proteins represent either lower abundant species in plasma or keratin contaminants (6 total), some of which could have potential value. Figure 5 shows the longitudinal $\mathrm{SpC}$ data for ovomacroglobulin (ovostatin). No peptides were detected in either the Healthy or EOC birds for the first three time points yet there is a significant increase in SpC's at time points 4 and 5 for the EOC bird. Ovomacroglobulin is a protease inhibitor from the $\alpha$-2-macroglobulin family which is synthesized in the oviduct and found in egg whites. ${ }^{90-92}$ Given that this study only involved two birds, it is premature to speculate as to the relationship between ovomacroglobulin and EOC or its potential as a biomarker. However, the data in Figure 5 illustrates key issues and inherent advantages to performing longitudinal sample analysis with regard to biomarker discovery. One of these issues that these data illustrate is that the MS-based proteomics workflow in this study straddles the detection limit for ovomacroglobulin. There is a possibility that the same upward trend is present for the Healthy dataset but that the magnitude of the change is smaller (i.e., analytical sensitivity). Such an effect could be masked in single-time point studies that could not measure significance at low sensitivities. Further investigation of the 73-sample biorepository will be necessary to assess ovomacroglobulin's relationship, if any, to EOC onset and progression. This will be accomplished via absolute quantification ${ }^{93-96}$ and/or Increased fractionation either at the sample preparation level or within the mass spectrometer (e.g., gas-phase fractionation ${ }^{97}$ ). 


\section{CONCLUSIONS}

A large scale biomarker discovery effort is reported that merges concepts rooted in the index-of-individuality with high performance MS-based proteomics, the chicken model of spontaneous epithelial ovarian cancer, and longitudinal sample collection with matched tissues. A unique biorepository was generated from 73 birds that included 5 longitudinal plasma samples collected at three month intervals for one year along with matched tissue samples from the healthy and cancerous birds. Within this 73 bird population, a total of 5 birds (6.8\%) were found to have epithelial ovarian cancer. Quantitative label-free MS-based proteomics was applied to longitudinal plasma sample sets from two birds within this 73bird biorepository; one bird that was otherwise healthy and a second bird with late stage EOC. The intra-individual variabilities of 80 plasma proteins in these two chickens were measured including estimates of analytical variability. Within sample precision was respectable with CV's less than $20 \%$ for more than $50 \%$ of the proteins at individual time points/replicates and approximately CV's of less than $30 \%$ were observed for $75 \%$ of the proteins. The $\mathrm{CV}_{\mathrm{A}}$ for 42 proteins was less than the $\mathrm{CV}_{\mathrm{W}}$ for either the Healthy or EOC birds allowing for discrimination between analytical and biological variability. The data presented in this study illustrate many of the challenges associated with global measurements of protein intra-individual variabilities. Fractionation is necessary to maximize proteome coverage but introduces variability both within and between sample sets. Moving forward with multiple longitudinal sample sets comprising healthy and EOC birds will require estimating the analytical variability within samples, between samples, and day of analysis. However, these challenges are shared in all biomarker discovery efforts and remain one of the most significant hurdles to global comparative proteomics. ${ }^{31}$

\section{Supplementary Material}

Refer to Web version on PubMed Central for supplementary material.

\section{Acknowledgments}

This work was financially supported by NIH-NCI through award K25CA128666 to A.M.H. We gratefully acknowledge Dr. James Attwood III (Bioinquire) for insightful discussions regarding label-free quantitative data analysis and interpretation. The apomyoglobin digestion protocol was generously provided by Kenneth L. Johnson (Mayo Clinic). We are grateful to Dr. Philip Andrews and Mark Gjukich (University of Michigan) for assistance with Tranche.

\section{REFERENCES}

1. Society, AC. Cancer Facts and Figures 2009. Atlanta: 2009.

2. Williams TI, Toups KL, Saggese DA, Kalli KR, Cliby WA, Muddiman DC. Epithelial ovarian cancer: disease etiology, treatment, detection, and investigational gene, metabolite, and protein biomarkers. J Proteome Res. 2007; 6(8):2936-62. [PubMed: 17583933]

3. Bast RC Jr. Feeney M, Lazarus H, Nadler LM, Colvin RB, Knapp RC. Reactivity of a monoclonal antibody with human ovarian carcinoma. J Clin Invest. 1981; 68(5):1331-7. [PubMed: 7028788]

4. Bast RC Jr. Klug TL, St John E, Jenison E, Niloff JM, Lazarus H, Berkowitz RS, Leavitt T, Griffiths CT, Parker L, Zurawski VR Jr. Knapp RC. A radioimmunoassay using a monoclonal antibody to monitor the course of epithelial ovarian cancer. N Engl J Med. 1983; 309(15):883-7. [PubMed: 6310399]

5. Menon U, Gentry-Maharaj A, Hallett R, Ryan A, Burnell M, Sharma A, Lewis S, Davies S, Philpott S, Lopes A, Godfrey K, Oram D, Herod J, Williamson K, Seif MW, Scott I, Mould T, Woolas R, Murdoch J, Dobbs S, Amso NN, Leeson S, Cruickshank D, McGuire A, Campbell S, Fallowfield L, Singh N, Dawnay A, Skates SJ, Parmar M, Jacobs I. Sensitivity and specificity of multimodal and ultrasound screening for ovarian cancer, and stage distribution of detected cancers: results of the 
prevalence screen of the UK Collaborative Trial of Ovarian Cancer Screening (UKCTOCS). Lancet Oncol. 2009; 10(4):327-40. [PubMed: 19282241]

6. Andersen MR, Goff BA, Lowe KA, Scholler N, Bergan L, Dresher CW, Paley P, Urban N. Combining a symptoms index with CA 125 to improve detection of ovarian cancer. Cancer. 2008; 113(3):484-489. [PubMed: 18615684]

7. Auersperg N, Wong AS, Choi KC, Kang SK, Leung PC. Ovarian surface epithelium: biology, endocrinology, and pathology. Endocr Rev. 2001; 22(2):255-88. [PubMed: 11294827]

8. Auersperg N, Ota T, Mitchell GW. Early events in ovarian epithelial carcinogenesis: progress and problems in experimental approaches. Int J Gynecol Cancer. 2002; 12(6):691-703. [PubMed: 12445245]

9. Cvetkovic D. Early events in ovarian oncogenesis. Reprod Biol Endocrinol. 2003; 1:68. [PubMed: 14577833]

10. Vanderhyden BC, Shaw TJ, Ethier JF. Animal models of ovarian cancer. Reprod Biol Endocrinol. 2003; 1:67. [PubMed: 14613552]

11. Ozols RF, Bookman MA, Connolly DC, Daly MB, Godwin AK, Schilder RJ, Xu X, Hamilton TC. Focus on epithelial ovarian cancer. Cancer Cell. 2004; 5(1):19-24. [PubMed: 14749123]

12. Garson K, Shaw TJ, Clark KV, Yao DS, Vanderhyden BC. Models of ovarian cancer - Are we there yet? Molecular and Cellular Endocrinology. 2005; 239(1-2):15-26. [PubMed: 15955618]

13. Bast RC Jr. Hennessy B, Mills GB. The biology of ovarian cancer: new opportunities for translation. Nat Rev Cancer. 2009; 9(6):415-28. [PubMed: 19461667]

14. Bartlett, J. Ovarian Cancer Methods and Protocols. Humana Press; Totawa: 2000. p. 817

15. Liu JS, Yang G, Thompson-Lanza JA, Glassman A, Hayes K, Patterson A, Marquez RT, Auersperg N, Yu YH, Hahn WC, Mills GB, Bast RC. A genetically defined model for human ovarian cancer. Cancer Research. 2004; 64(5):1655-1663. [PubMed: 14996724]

16. Orsulic S, Li Y, Soslow RA, Vitale-Cross LA, Gutkind JS, Varmus HE. Induction of ovarian cancer by defined multiple genetic changes in a mouse model system. Cancer Cell. 2002; 1(1):5362. [PubMed: 12086888]

17. Connolly DC, Bao R, Nikitin AY, Stephens KC, Poole TW, Hua X, Harris SS, Vanderhyden BC, Hamilton TC. Female mice chimeric for expression of the simian virus $40 \mathrm{TAg}$ under control of the MISIIR promoter develop epithelial ovarian cancer. Cancer Research. 2003; 63(6):1389-1397. [PubMed: 12649204]

18. Flesken-Nikitin A, Choi KC, Eng JP, Shmidt EN, Nikitin AY. Induction of carcinogenesis by concurrent inactivation of p53 and Rb1 in the mouse ovarian surface epithelium. Cancer Research. 2003; 63(13):3459-3463. [PubMed: 12839925]

19. Dinulescu DM, Ince TA, Quade BJ, Shafer SA, Crowley D, Jacks T. Role of K-ras and Pten in the development of mouse models of endometriosis and endometrioid ovarian cancer. Nature Medicine. 2005; 11(1):63-70.

20. Orsulic, S. Ovarian Cancer. In: Holland, EC., editor. Mouse Models of Human Cancer. Wiley-Liss; Hoboken: 2004. p. 171-187.

21. Wilson JE. Adeno-carcinomata in hens kept in a constant environment. Poultry Science. 1958; $37: 1253$.

22. Fredrickson TN. Ovarian tumors of the hen. Environ Health Perspect. 1987; 73:35-51. [PubMed: 3665870]

23. Rodriguez-Burford C, Barnes MN, Berry W, Partridge EE, Grizzle WE. Immunohistochemical expression of molecular markers in an avian model: a potential model for preclinical evaluation of agents for ovarian cancer chemoprevention. Gynecol Oncol. 2001; 81(3):373-9. [PubMed: 11371125]

24. Giles JR, Olson LM, Johnson PA. Characterization of ovarian surface epithelial cells from the hen: a unique model for ovarian cancer. Exp Biol Med (Maywood). 2006; 231(11):1718-25. [PubMed: 17138758]

25. Urick ME, Johnson PA. Cyclooxygenase 1 and 2 mRNA and protein expression in the Gallus domesticus model of ovarian cancer. Gynecol Oncol. 2006; 103(2):673-8. [PubMed: 16797680] 
26. Jackson E, Anderson K, Ashwell C, Petitte J, Mozdziak PE. CA125 expression in spontaneous ovarian adenocarcinomas from laying hens. Gynecol Oncol. 2007; 104(1):192-8. [PubMed: 16942793]

27. Stammer K, Edassery SL, Barua A, Bitterman P, Bahr JM, Hales DB, Luborsky JL. SeleniumBinding Protein 1 expression in ovaries and ovarian tumors in the laying hen, a spontaneous model of human ovarian cancer. Gynecol Oncol. 2008; 109(1):115-21. [PubMed: 18272210]

28. Hakim AA, Barry CP, Barnes HJ, Anderson KE, Petitte J, Whitaker R, Lancaster JM, Wenham RM, Carver DK, Turbov J, Berchuck A, Kopelovich L, Rodriguez GC. Ovarian adenocarcinomas in the laying hen and women share similar alterations in p53, ras, and HER-2/neu. Cancer Prev Res (Phila Pa). 2009; 2(2):114-21.

29. Urick ME, Giles JR, Johnson PA. Dietary aspirin decreases the stage of ovarian cancer in the hen. Gynecol Oncol. 2009; 112(1):166-70. [PubMed: 18986688]

30. Fathalla MF. Incessant ovulation--a factor in ovarian neoplasia? Lancet. 1971; 2(7716):163. [PubMed: 4104488]

31. Hawkridge AM, Muddiman DC. Mass Spectrometry-Based Biomarker Discovery: Towards a Global Proteome Index of Individuality. Annual Review of Analytical Chemistry. 2009; 2:265278.

32. Faca VM, Hanash SM. In-depth proteomics to define the cell surface and secretome of ovarian cancer cells and processes of protein shedding. Cancer Res. 2009; 69(3):728-30. [PubMed: 19155298]

33. Morita A, Miyagi E, Yasumitsu H, Kawasaki H, Hirano H, Hirahara F. Proteomic search for potential diagnostic markers and therapeutic targets for ovarian clear cell adenocarcinoma. Proteomics. 2006; 6(21):5880-90. [PubMed: 17022098]

34. Smith-Beckerman DM, Fung KW, Williams KE, Auersperg N, Godwin AK, Burlingame AL. Proteome changes in ovarian epithelial cells derived from women with BRCA1 mutations and family histories of cancer. Molecular \& Cellular Proteomics. 2005; 4(2):156-168. [PubMed: 15591324]

35. Gunawardana CG, Kuk C, Smith CR, Batruch I, Soosaipillai A, Diamandis EP. Comprehensive Analysis of Conditioned Media from Ovarian Cancer Cell Lines Identifies Novel Candidate Markers of Epithelial Ovarian Cancer. Journal of Proteome Research. 2009; 8(10):4705-4713. [PubMed: 19663500]

36. Pitteri SJ, JeBailey L, Faca VM, Thorpe JD, Silva MA, Ireton RC, Horton MB, Wang H, Pruitt LC, Zhang Q, Cheng KH, Urban N, Hanash SM, Dinulescu DM. Integrated proteomic analysis of human cancer cells and plasma from tumor bearing mice for ovarian cancer biomarker discovery. PLoS One. 2009; 4(11):e7916. [PubMed: 19936259]

37. Faca VM, Ventura AP, Fitzgibbon MP, Pereira-Faca SR, Pitteri SJ, Green AE, Ireton RC, Zhang Q, Wang H, O'Briant KC, Drescher CW, Schummer M, McIntosh MW, Knudsen BS, Hanash SM. Proteomic analysis of ovarian cancer cells reveals dynamic processes of protein secretion and shedding of extra-cellular domains. PLoS One. 2008; 3(6):e2425. [PubMed: 18560578]

38. Wang Y, Wu R, Cho KR, Thomas DG, Gossner G, Liu JR, Giordano TJ, Shedden KA, Misek DE, Lubman DM. Differential protein mapping of ovarian serous adenocarcinomas: identification of potential markers for distinct tumor stage. J Proteome Res. 2009; 8(3):1452-63. [PubMed: 19159301]

39. Wang H, Kachman MT, Schwartz DR, Cho KR, Lubman DM. Comprehensive proteome analysis of ovarian cancers using liquid phase separation, mass mapping and tandem mass spectrometry: a strategy for identification of candidate cancer biomarkers. Proteomics. 2004; 4(8):2476-95. [PubMed: 15274142]

40. He QY, Zhou Y, Wong E, Ehlen TG, Auersperg N, Chiu JF, Wong AST. Proteomic analysis of a preneoplastic phenotype in ovarian surface epithelial cells derived from prophylactic oophorectomies. Gynecologic Oncology. 2005; 98(1):68-76. [PubMed: 15913737]

41. Bengtsson S, Krogh M, Szigyarto CAK, Uhlen M, Schedvins K, Silfversward C, Linder S, Auer G, Alaiya A, James P. Large-scale proteomics analysis of human ovarian cancer for biomarkers. Journal of Proteome Research. 2007; 6(4):1440-1450. [PubMed: 17315909] 
42. Kuk C, Kulasingam V, Gunawardana CG, Smith CR, Batruch I, Diamandis EP. Mining the Ovarian Cancer Ascites Proteome for Potential Ovarian Cancer Biomarkers. Molecular \& Cellular Proteomics. 2009; 8(4):661-669. [PubMed: 19047685]

43. Gortzak-Uzan L, Ignatchenko A, Evangelou AI, Agochiya M, Brown KA, Onge PS, Kireeva I, Schmitt-Ulms G, Brown TJ, Murphy J, Rosen B, Shaw P, Jurisica I, Kislinger T. A proteome resource of ovarian cancer ascites: Integrated proteomic and bioinformatic analyses to identify putative biomarkers. Journal of Proteome Research. 2008; 7(1):339-351. [PubMed: 18076136]

44. Lopez MF, Mikulskis A, Kuzdzal S, Golenko E, Petricoin EF 3rd, Liotta LA, Patton WF, Whiteley GR, Rosenblatt K, Gurnani P, Nandi A, Neill S, Cullen S, O’Gorman M, Sarracino D, Lynch C, Johnson A, McKenzie W, Fishman D. A novel, high-throughput workflow for discovery and identification of serum carrier protein-bound peptide biomarker candidates in ovarian cancer samples. Clin Chem. 2007; 53(6):1067-74. [PubMed: 17463175]

45. Ahmed N, Oliva KT, Barker G, Hoffmann P, Reeve S, Smith IA, Quinn MA, Rice GE. Proteomic tracking of serum protein isoforms as screening biomarkers of ovarian cancer. Proteomics. 2005; 5(17):4625-36. [PubMed: 16220531]

46. Moshkovskii SA, Serebryakova MV, Kuteykin-Teplyakov KB, Tikhonova OV, Goufman EI, Zgoda VG, Taranets IN, Makarov OV, Archakov AI. Ovarian cancer marker of $11.7 \mathrm{kDa}$ detected by proteomics is a serum amyloid A1. Proteomics. 2005; 5(14):3790-7. [PubMed: 16121334]

47. Ahmed N, Barker G, Oliva KT, Hoffmann P, Riley C, Reeve S, Smith AI, Kemp BE, Quinn MA, Rice GE. Proteomic-based identification of haptoglobin-1 precursor as a novel circulating biomarker of ovarian cancer. Br J Cancer. 2004; 91(1):129-40. [PubMed: 15199385]

48. Ye B, Cramer DW, Skates SJ, Gygi SP, Pratomo V, Fu L, Horick NK, Licklider LJ, Schorge JO, Berkowitz RS, Mok SC. Haptoglobin-alpha subunit as potential serum biomarker in ovarian cancer: identification and characterization using proteomic profiling and mass spectrometry. Clin Cancer Res. 2003; 9(8):2904-11. [PubMed: 12912935]

49. Bergen HR, Vasmatzis G, Cliby WA, Johnson KL, Oberg AL, Muddiman DC. Discovery of ovarian cancer biomarkers in serum using NanoLC electrospray ionization TOF and FT-ICR mass spectrometry. Disease Markers. 2003; 19(4-5):239-249. [PubMed: 15266667]

50. Zhang Z, Bast RC, Yu YH, Li JN, Sokoll LJ, Rai AJ, Rosenzweig JM, Cameron B, Wang YY, Meng XY, Berchuck A, van Haaften-Day C, Hacker NF, de Bruijn HWA, van der Zee AGJ, Jacobs IJ, Fung ET, Chan DW. Three biomarkers identified from serum proteomic analysis for the detection of early stage ovarian cancer. Cancer Research. 2004; 64(16):5882-5890. [PubMed: 15313933]

51. Cotlove E, Harris EK, Williams GZ. Biological and Analytic Components of Variation in LongTerm Studies of Serum Constituents in Normal Subjects .3. Physiological and Medical Implications. Clinical Chemistry. 1970; 16(12):1028. [PubMed: 5481563]

52. Harris EK, Kanofsky P, Shakarji G, Cotlove E. Biological and Analytic Components of Variation in Long-Term Studies of Serum Constituents in Normal Subjects .2. Estimating Biological Components of Variation. Clinical Chemistry. 1970; 16(12):1022. [PubMed: 5481562]

53. Williams GZ, Young DS, Stein MR, Cotlove E. Biological and analytic components of variation in long-term studies of serum constituents in normal subjects. I. Objectives, subject selection, laboratory procedures, and estimation of analytic deviation. Clin Chem. 1970; 16(12):1016-21. [PubMed: 5481561]

54. Harris EK, Demets DL. Biological and Analytic Components of Variation in Long-Term Studies of Serum Constituents in Normal Subjects .5. Estimated Biological Variations in Ionized Calcium. Clinical Chemistry. 1971; 17(10):983-987. [PubMed: 5095152]

55. Young DS, Harris EK, Cotlove E. Biological and Analytic Components of Variation in Long-Term Studies of Serum Constituents in Normal Subjects .4. Results of a Study Design to Eliminate Long-Term Analytic Deviations. Clinical Chemistry. 1971; 17(5):403. [PubMed: 5573406]

56. Harris EK. Effects of Intraindividual and Interindividual Variation on Appropriate Use of Normal Ranges. Clinical Chemistry. 1974; 20(12):1535-1542. [PubMed: 4430131]

57. McPherson, RA.; Pincus, MR. Henry's Clinical Diagnosis and Management by Laboratory Methods. 21 ed.. Saunders Elsevier; Philadelphia: 2007. p. 1450 
58. Tuxen MK, Soletormos G, Petersen PH, Schioler V, Dombernowsky P. Assessment of biological variation and analytical imprecision of CA 125, CEA, and TPA in relation to monitoring of ovarian cancer. Gynecologic Oncology. 1999; 74(1):12-22. [PubMed: 10385546]

59. Tuxen MK, Soletormos G, Rustin GJ, Nelstrop AE, Dombernowsky P. Biological variation and analytical imprecision of CA 125 in patients with ovarian cancer. Scand J Clin Lab Invest. 2000; 60(8):713-21. [PubMed: 11218154]

60. Skates SJ, Xu FJ, Yu YH, Sjovall K, Einhorn N, Chang Y, Bast RC Jr. Knapp RC. Toward an optimal algorithm for ovarian cancer screening with longitudinal tumor markers. Cancer. 1995; 76(10 Suppl):2004-10. [PubMed: 8634992]

61. Soletormos G, Schioler V, Nielsen D, Skovsgaard T, Dombernowsky P. Interpretation of Results for Tumor-Markers on the Basis of Analytical Imprecision and Biological Variation. Clinical Chemistry. 1993; 39(10):2077-2083. [PubMed: 8403393]

62. Richardson, RW. Handbook of Nonpathologic Variations in Human Blood Constituents. CRC Press; 1994. p. 343

63. Harris, EK.; Boyd, JC. Statistical Bases of Reference Values in Laboratory Medicine. Vol. 146. Marcel Dekker, Inc.; New York: 1995. p. 361

64. Anderson NL, Anderson NG. The human plasma proteome - History, character, and diagnostic prospects. Molecular \& Cellular Proteomics. 2002; 1(11):845-867. [PubMed: 12488461]

65. Davis MT, Auger P, Spahr C, Patterson SD. Cancer biomarker discovery via low molecular weight serum proteome profiling - Where is the tumor? Proteomics Clinical Applications. 2007; 1(12): 1545-1558. [PubMed: 21136654]

66. Candiano G, Bruschi M, Musante L, Santucci L, Ghiggeri GM, Carnemolla B, Orecchia P, Zardi L, Righetti PG. Blue silver: A very sensitive colloidal Coomassie G-250 staining for proteome analysis. Electrophoresis. 2004; 25(9):1327-1333. [PubMed: 15174055]

67. Shevchenko A, Tomas H, Havlis J, Olsen JV, Mann M. In-gel digestion for mass spectrometric characterization of proteins and proteomes. Nature Protocols. 2006; 1(6):2856-2860.

68. Andrews GL, Shuford CM, Burnett JC, Hawkridge AM, Muddiman DC. Coupling of a vented column with splitless nanoRPLC-ESI-MS for the improved separation and detection of brain natriuretic peptide-32 and its proteolytic peptides. Journal of Chromatography B-Analytical Technologies in the Biomedical and Life Sciences. 2009; 77(10):948-954.

69. Keller A, Nesvizhskii AI, Kolker E, Aebersold R. Empirical statistical model to estimate the accuracy of peptide identifications made by MS/MS and database search. Analytical Chemistry. 2002; 74(20):5383-5392. [PubMed: 12403597]

70. Nesvizhskii AI, Keller A, Kolker E, Aebersold R. A statistical model for identifying proteins by tandem mass spectrometry. Analytical Chemistry. 2003; 75(17):4646-4658. [PubMed: 14632076]

71. Weatherly DB, Atwood JA, Minning TA, Cavola C, Tarleton RL, Orlando R. A heuristic method for assigning a false-discovery rate for protein identifications from mascot database search results. Molecular \& Cellular Proteomics. 2005; 4(6):762-772. [PubMed: 15703444]

72. Ong SE, Mann M. Mass spectrometry-based proteomics turns quantitative. Nat Chem Biol. 2005; 1(5):252-62. [PubMed: 16408053]

73. Chelius D, Bondarenko PV. Quantitative profiling of proteins in complex mixtures using liquid chromatography and mass spectrometry. Journal of Proteome Research. 2002; 1(4):317-323. [PubMed: 12645887]

74. Bondarenko PV, Chelius D, Shaler TA. Identification and relative quantitation of protein mixtures by enzymatic digestion followed by capillary reversed-phase liquid chromatography-tandem mass spectrometry. Analytical Chemistry. 2002; 74(18):4741-4749. [PubMed: 12349978]

75. Wang WX, Zhou HH, Lin H, Roy S, Shaler TA, Hill LR, Norton S, Kumar P, Anderle M, Becker $\mathrm{CH}$. Quantification of proteins and metabolites by mass spectrometry without isotopic labeling or spiked standards. Analytical Chemistry. 2003; 75(18):4818-4826. [PubMed: 14674459]

76. Higgs RE, Knierman MD, Gelfanova V, Butler JP, Hale JE. Comprehensive label-free method for the relative quantification of proteins from biological samples. Journal of Proteome Research. 2005; 4(4):1442-1450. [PubMed: 16083298] 
77. Johnson KL, Mason CJ, Muddiman DC, Eckel JE. Analysis of the low molecular weight fraction of serum by LC-dual ESI-FT-ICR mass spectrometry: Precision of retention time, mass, and ion abundance. Analytical Chemistry. 2004; 76(17):5097-5103. [PubMed: 15373448]

78. Paoletti AC, Parmely TJ, Tomomori-Sato C, Sato S, Zhu DX, Conaway RC, Conaway JW, Florens L, Washburn MP. Quantitative proteomic analysis of distinct mammalian Mediator complexes using normalized spectral abundance factors. Proceedings of the National Academy of Sciences of the United States of America. 2006; 03(50):18928-18933. [PubMed: 17138671]

79. Rappsilber J, Ryder U, Lamond AI, Mann M. Large-scale proteomic analysis of the human splicesome. Genome Research. 2002; 12(8):1231-1245. [PubMed: 12176931]

80. Liu HB, Sadygov RG, Yates JR. A model for random sampling and estimation of relative protein abundance in shotgun proteomics. Analytical Chemistry. 2004; 76(14):4193-4201. [PubMed: 15253663]

81. Wiener MC, Sachs JR, Deyanova EG, Yates NA. Differential mass spectrometry: A label-free LCMS method for finding significant differences in complex peptide and protein mixtures. Analytical Chemistry. 2004; 76(20):6085-6096. [PubMed: 15481957]

82. Ishihama Y, Oda Y, Tabata T, Sato T, Nagasu T, Rappsilber J, Mann M. Exponentially modified protein abundance index (emPAI) for estimation of absolute protein amount in proteomics by the number of sequenced peptides per protein. Molecular \& Cellular Proteomics. 2005; 4(9):12651272. [PubMed: 15958392]

83. Pavelka N, Fournier ML, Swanson SK, Pelizzola M, Ricciardi-Castagnoli P, Florens L, Washburn MP. Statistical similarities between transcriptomics and quantitative shotgun proteomics data. Molecular \& Cellular Proteomics. 2008; 7(4):631-644. [PubMed: 18029349]

84. Choi H, Fermin D, Nesvizhskii AI. Significance Analysis of Spectral Count Data in Label-free Shotgun Proteomics. Molecular \& Cellular Proteomics. 2008; 7(12):2373-2385. [PubMed: 18644780]

85. Zhang B, VerBerkmoes NC, Langston MA, Uberbacher E, Hettich RL, Samatova NF. Detecting differential and correlated protein expression in label-free shotgun proteomics. Journal of Proteome Research. 2006; 5(11):2909-2918. [PubMed: 17081042]

86. Colinge J, Chiappe D, Lagache S, Moniatte M, Bougueleret L. Differential proteomics via probabilistic peptide identification scores. Analytical Chemistry. 2005; 77(2):596-606. [PubMed: 15649059]

87. Old WM, Meyer-Arendt K, Aveline-Wolf L, Pierce KG, Mendoza A, Sevinsky JR, Resing KA, Ahn NG. Comparison of label-free methods for quantifying human proteins by shotgun proteomics. Molecular \& Cellular Proteomics. 2005; 4(10):1487-1502. [PubMed: 15979981]

88. Gao BB, Stuart L, Feener EP. Label-free Quantitative Analysis of One-dimensional PAGE LC/ MS/MS Proteome. Molecular \& Cellular Proteomics. 2008; 7(12):2399-2409. [PubMed: 18676994]

89. Whittow, GC. Sturkie's Avian Physiology. 5th ed.. Academic Press; San Diego: 2000. p. 685

90. Nagase H, Harris ED, Woessner JF, Brew K. Ovostatin - a Novel Proteinase-Inhibitor from Chicken Egg-White .1. Purification, Physicochemical Properties, and Tissue Distribution of Ovostatin. Journal of Biological Chemistry. 1983; 258(12):7481-7489. [PubMed: 6408074]

91. Saxena I, Tayyab S. Protein proteinase inhibitors from avian egg whites. Cellular and Molecular Life Sciences. 1997; 3(1):13-23. [PubMed: 9117993]

92. Mann K. The chicken egg white proteome. Proteomics. 2007; 7(19):3558-3568. [PubMed: 17722208]

93. Barr JR, Maggio VL, Patterson DG, Cooper GR, Henderson LO, Turner WE, Smith SJ, Hannon WH, Needham LL, Sampson EJ. Isotope dilution mass spectrometric quantification of specific proteins: Model application with apolipoprotein A-I. Clinical Chemistry. 1996; 42(10):1676-1682. [PubMed: 8855153]

94. Barnidge DR, Goodmanson MK, Klee GG, Muddiman DC. Absolute quantification of the model biomarker prostate-specific antigen in serum by LC-MS/MS using protein cleavage and isotope dilution mass spectrometry. Journal of Proteome Research. 2004; 3(3):644-652. [PubMed: 15253448] 
95. Williams DK, Muddiman DC. Absolute Quantification of C-Reactive Protein in Human Plasma Derived from Patients with Epithelial Ovarian Cancer Utilizing Protein Cleavage Isotope Dilution Mass Spectrometry. Journal of Proteome Research. 2009; 8(2):1085-1090. [PubMed: 19196186]

96. Kuhn E, Wu J, Karl J, Liao H, Zolg W, Guild B. Quantification of C-reactive protein in the serum of patients with rheumatoid arthritis using multiple reaction monitoring mass spectrometry and C-13-labeled peptide standards. Proteomics. 2004; 4(4):1175-1186. [PubMed: 15048997]

97. Spahr CS, Davis MT, McGinley MD, Robinson JH, Bures EJ, Beierle J, Mort J, Courchesne PL, Chen K, Wahl RC, Yu W, Luethy R, Patterson SD. Towards defining the urinary proteome using liquid chromatography-tandem mass spectrometry I. Profiling an unfractionated tryptic digest. Proteomics. 2001; 1(1):93-107. [PubMed: 11680902] 

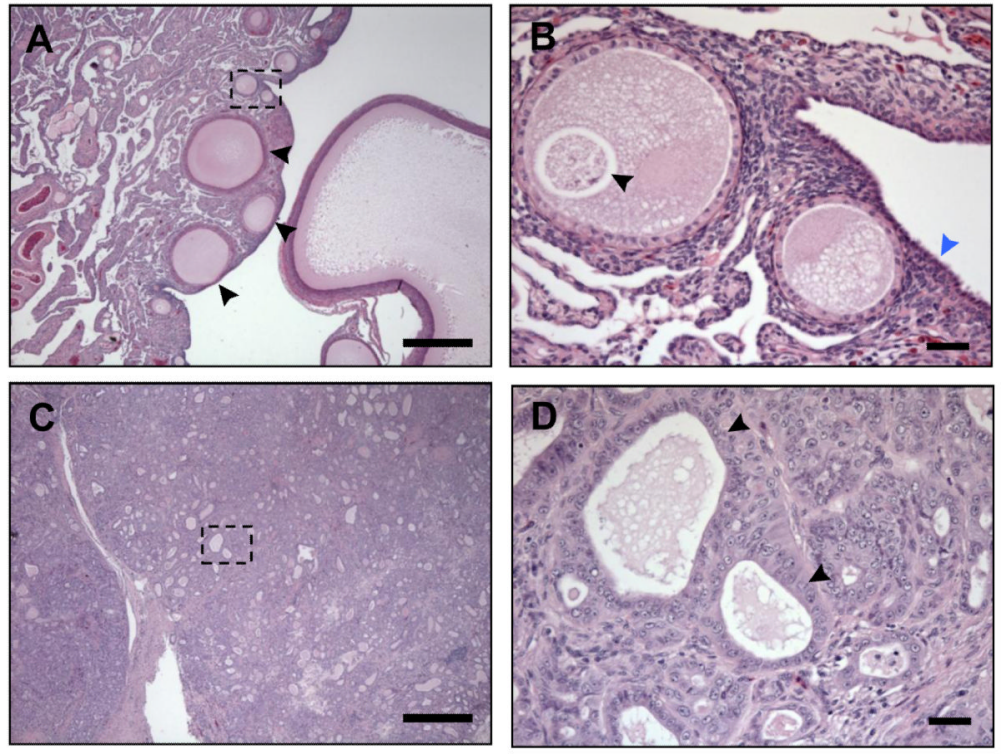

Figure 1.

Hematoxylin and eosin stained tissue sections for the Healthy bird (602B) with a fully functional ovary at $4 \times(\mathbf{A})$ and $20 \times(\mathbf{B})$ and a late stage EOC bird $(650 \mathrm{~B})$ at $4 \times(\mathbf{C})$ and $20 \times$ (D). The dashed boxes in (A) and (C) indicate the magnified regions in images (B) and (D). Black arrows indicate immature follicles for the Healthy bird (A). Black arrow indicates an oocyte within an immature follicle and the blue arrow indicates the ovarian surface epithelial (OSE) layer (B). Neoplastic cells invading the ovarian stroma (C). Dilated cystic glands and glandular structures of variable-size indicated by yellow arrows (D). Scale bars at $4 \times$ in (A) and $(\mathbf{C})=1 \mathrm{~mm}$ and at $20 \times$ in $(\mathbf{B})$ and $(\mathbf{D})=100 \mu \mathrm{m}$. 
A

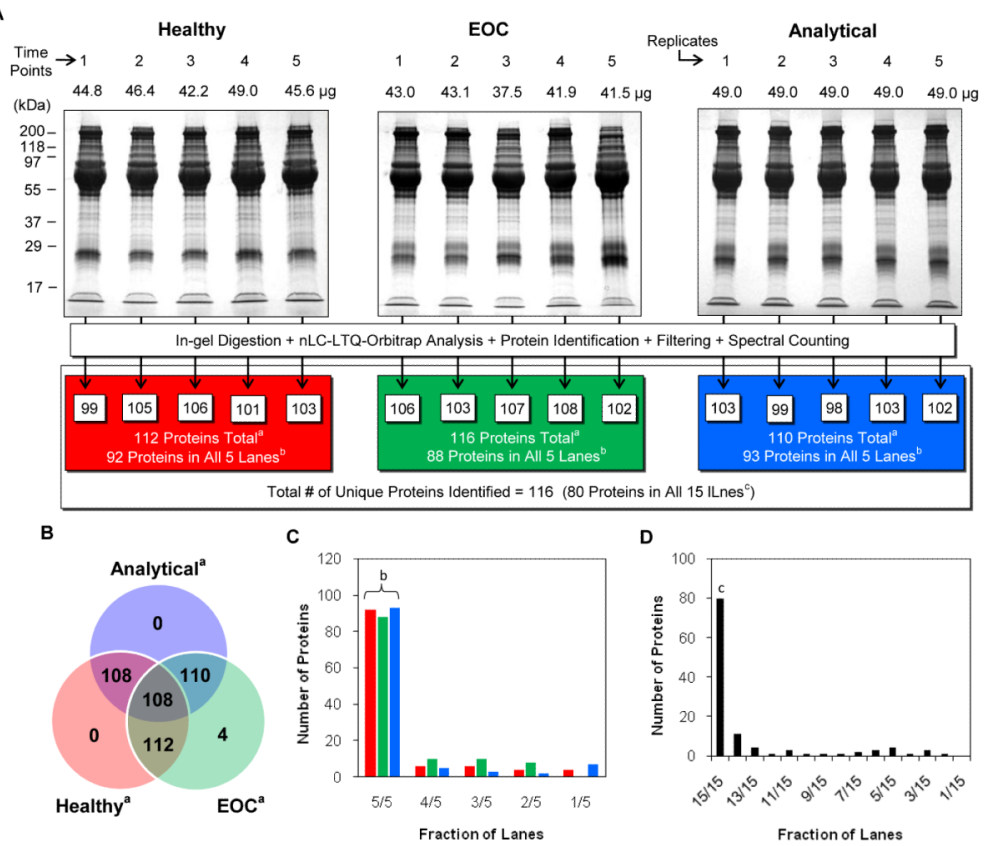

Figure 2.

One-dimensional gels of longitudinal plasma samples from Healthy (red), EOC (green), and Analytical (blue) birds with corresponding time points/replicates and total protein $(\mu \mathrm{g})$ loaded onto each lane. The total numbers of proteins identified from each gel lane, in each bird, and for the entire study are provided directly below the 1D-gels. (A) Venn diagram showing the identified protein overlap between the Healthy, EOC, and Analytical sample sets.(B) The number of proteins in the Healthy (red), EOC (green), and Analytical (blue) plotted as function of fraction of proteins identified per lane.(C) The number of proteins identified plotted as a function of fraction of proteins identified per lane.(D) Note: ${ }^{\mathrm{a}, \mathrm{b}, \mathrm{c}}$ denote the source of the numbers between Figure 1A and 1B, 1C, and 1D. 


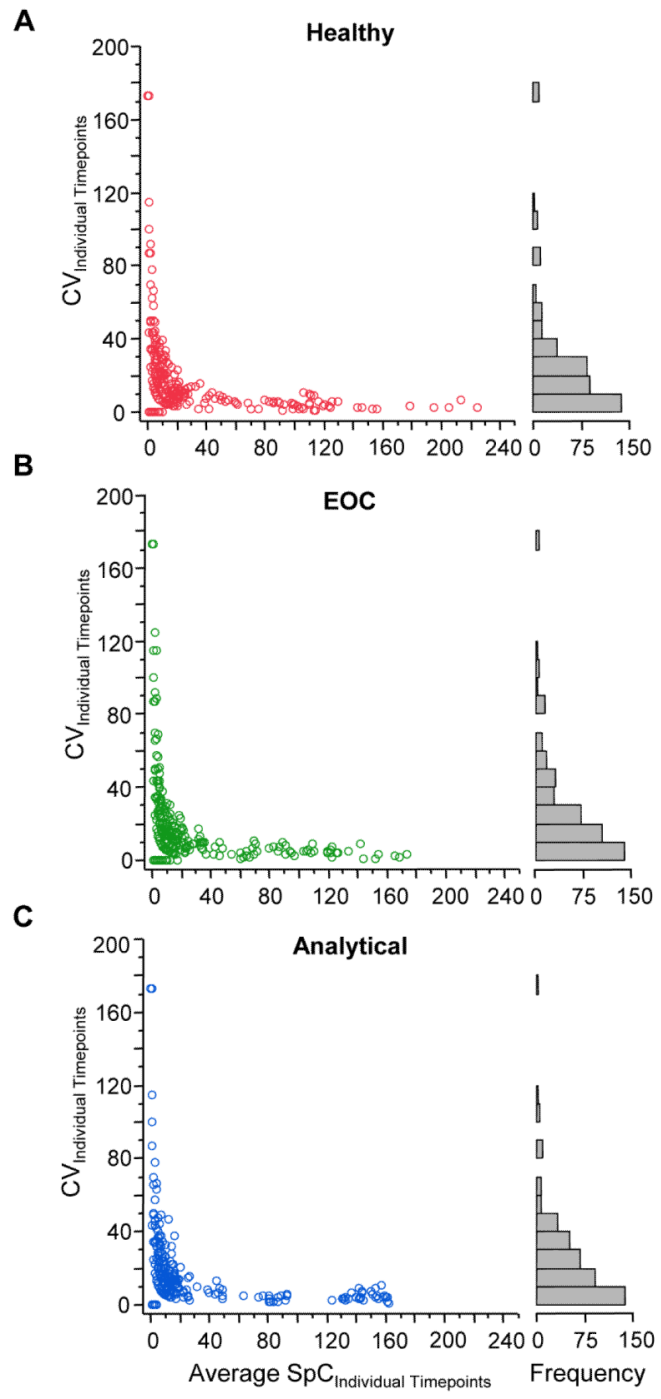

Figure 3.

The coefficient of variation $(\%)$ at each time point $\left(\mathrm{CV}_{\text {Individual Timepoints }}\right)$ for the 80 proteins identified in all $15 \mathrm{gel}$ lanes plotted as a function of the average spectral counts (Average $\mathrm{SpC}$ ). A histogram plotting the number of proteins (Frequency) relative to the $\mathrm{CV}_{\text {Individual Timepoints }}$ in $10 \%$ bin widths adjoins each plot. Healthy (A), EOC (B), and Analytical (C) birds. 

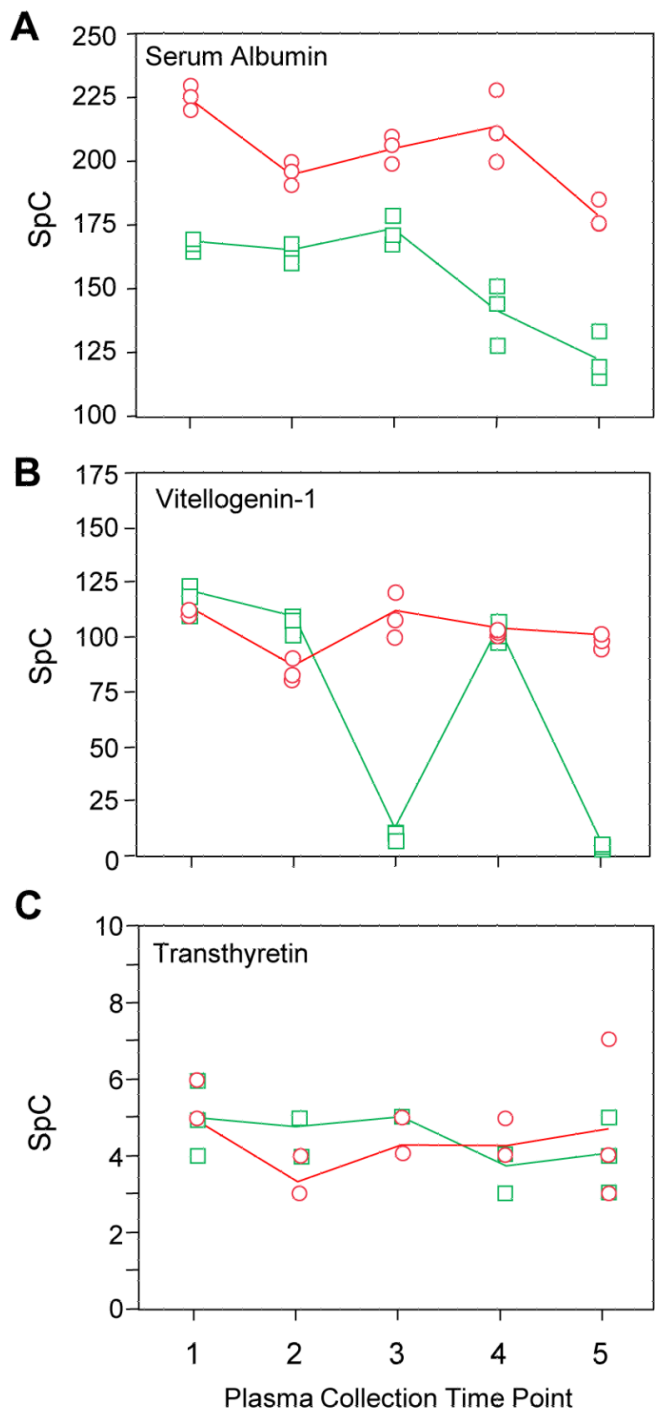

Figure 4.

Quantitative SpC data for the Healthy (red) and EOC (green) birds plotted as a function of sampling time point are shown for serum albumin (A), vitellogenin-1 (B), and transthyretin (C). The solid lines terminate at the average $\mathrm{SpC}(\mathrm{n}=3)$ for each time point. 


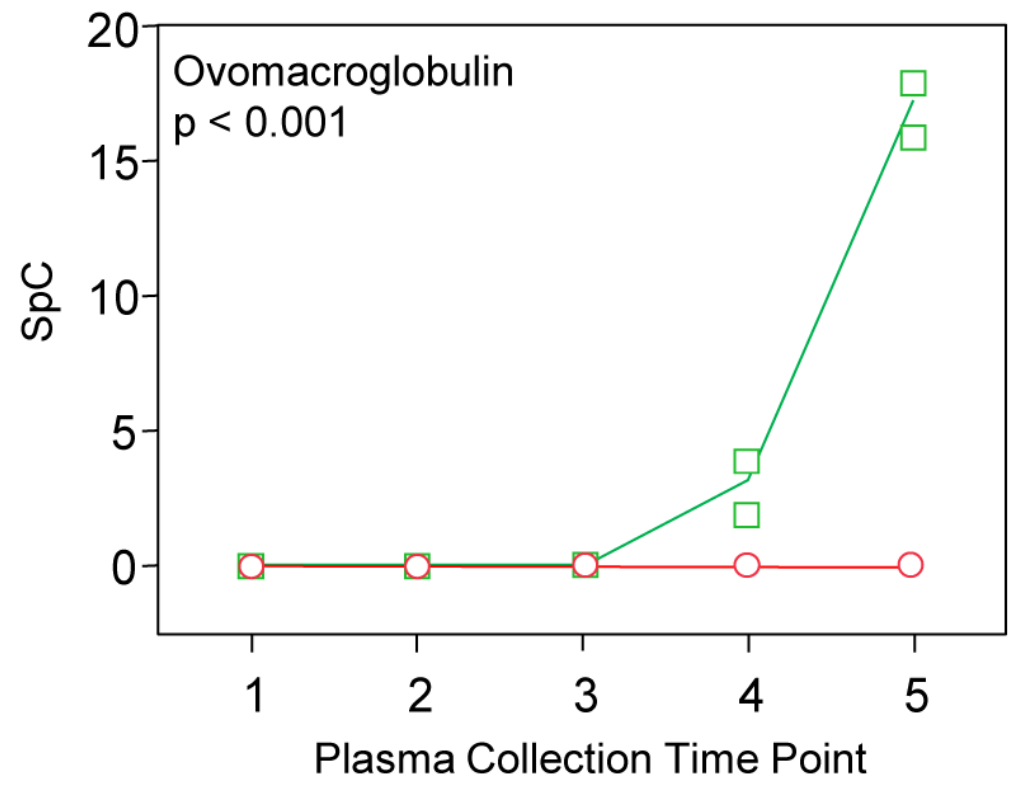

Figure 5.

Quantitative SpC data for the Healthy (red) and EOC (green) birds plotted as a function of sampling time point for ovomacroglobulin. The solid lines terminate at the average SpC $(n=3)$ for each time point. The p-value $(<0.001)$ is the probability that the that the SpC differences between time points for the EOC bird are insignificant (ANOVA). 


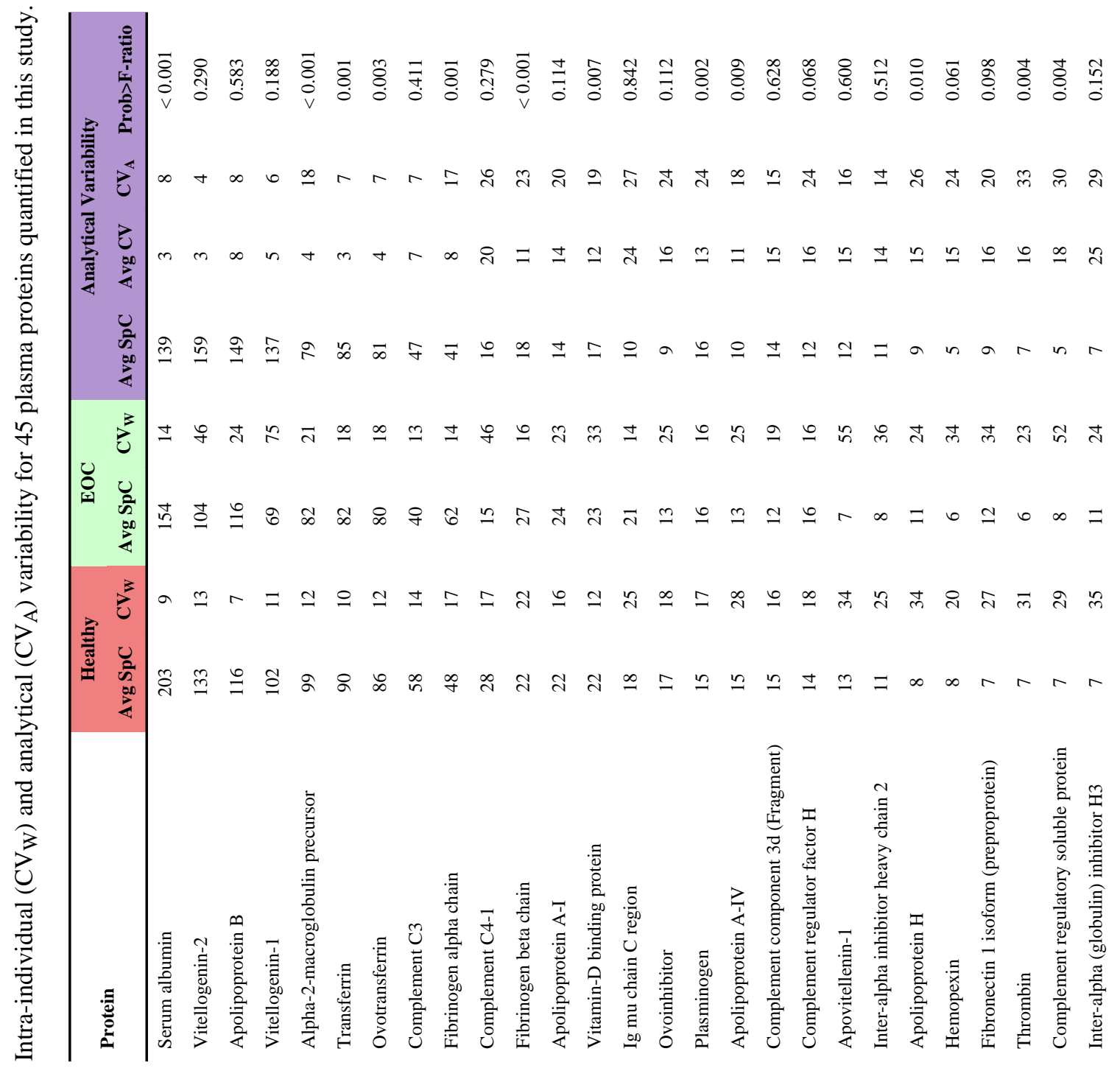
Anal Bioanal Chem. Author manuscript; available in PMC 2011 September 1. 


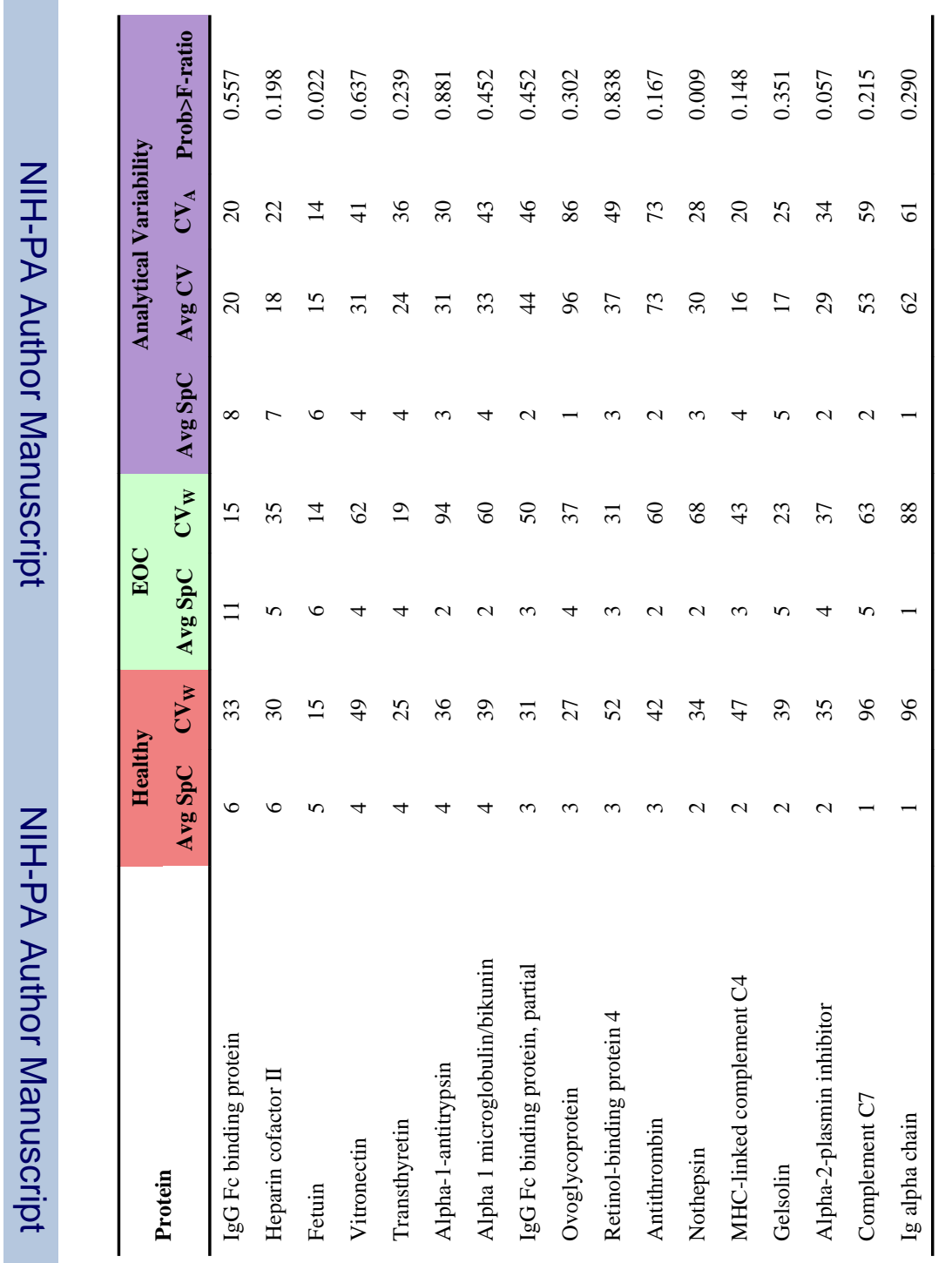

